\title{
QUEEN'S
UNIVERSITY
BELFAST
}

\section{Do persistent organic pollutants interact with the stress response? Individual compounds, and their mixtures, interaction with the glucocorticoid receptor}

Wilson, J., Berntsen, H. F., Elisabeth Zimmer, K., Verhaegen, S., Frizzell, C., Ropstad, E., \& Connolly, L. (2016). Do persistent organic pollutants interact with the stress response? Individual compounds, and their mixtures, interaction with the glucocorticoid receptor. Toxicology Letters, 241, 121-132.

https://doi.org/10.1016/j.toxlet.2015.11.014

\section{Published in:}

Toxicology Letters

\section{Document Version:}

Peer reviewed version

Queen's University Belfast - Research Portal:

Link to publication record in Queen's University Belfast Research Portal

\section{Publisher rights}

(C) 2015 Elsevier Ireland Ltd

This is an open access article published under a Creative Commons Attribution-NonCommercial-NoDerivs License

(https://creativecommons.org/licenses/by-nc-nd/4.0/), which permits distribution and reproduction for non-commercial purposes, provided the author and source are cited.

\section{General rights}

Copyright for the publications made accessible via the Queen's University Belfast Research Portal is retained by the author(s) and / or other copyright owners and it is a condition of accessing these publications that users recognise and abide by the legal requirements associated with these rights.

Take down policy

The Research Portal is Queen's institutional repository that provides access to Queen's research output. Every effort has been made to ensure that content in the Research Portal does not infringe any person's rights, or applicable UK laws. If you discover content in the

Research Portal that you believe breaches copyright or violates any law, please contact openaccess@qub.ac.uk. 
Do persistent organic pollutants interact with the stress response? Individual compounds, and their mixtures, interaction with the glucocorticoid receptor.

Jodie Wilson ${ }^{\mathrm{a}}$, Hanne Friis Berntsen ${ }^{\mathrm{b}}$, Karin Elisabeth Zimmer ${ }^{\mathrm{b}}$, Steven Verhaegen ${ }^{\mathrm{b}}$, Caroline Frizzella, Erik Ropstad ${ }^{b}$, Lisa Connolly*

aInstitute for Global Food Security, School of Biological Sciences, Queen's University Belfast, Northern Ireland, United Kingdom

${ }^{\mathrm{b}}$ Norwegian University of Life Sciences, Oslo, Norway.

*Corresponding author: I.connolly@qub.ac.uk +44 28 90976668; fax: +44 2890976513.

Abstract

Persistent organic pollutants (POPs) are toxic substances, highly resistant to environmental degradation, which can bio-accumulate and have long-range atmospheric transport potential (UNEP 2001). The majority of studies on endocrine disruption have focused on interferences on the sexual steroid hormones and so have overlooked disruption to glucocorticoid hormones. Here the endocrine disrupting potential of individual POPs and their mixtures has been investigated in vitro to identify any disruption to glucocorticoid nuclear receptor transcriptional activity. POP mixtures were screened for glucocorticoid receptor (GR) translocation using a GR redistribution assay (RA) on a Celllnsight ${ }^{\mathrm{TM}}$ NXT High Content Screening (HCS) platform. A mammalian reporter gene assay (RGA) was then used to assess the individual POPs, and their mixtures, for effects on glucocorticoid nuclear receptor transactivation. POP mixtures did not induce GR translocation in the GR RA or produce an agonist response in the GR RGA. However, in the antagonist test, in the presence of cortisol, an individual POP, $p, p^{\prime}$-dichlorodiphenyldichloroethylene $\left(p, p^{\prime}\right.$-DDE), was found to decrease glucocorticoid nuclear receptor transcriptional activity to $72.5 \%$ (in comparison to the positive cortisol control). Enhanced nuclear transcriptional activity, in the presence of cortisol, was evident for the two lowest concentrations of perfluorodecanoic acid (PFOS) potassium salt $(0.0147 \mathrm{mg} / \mathrm{ml}$ and $0.0294 \mathrm{mg} / \mathrm{ml}$ ), the two highest concentrations of perfluorodecanoic acid (PFDA) $(0.0025 \mathrm{mg} / \mathrm{ml}$ and $0.005 \mathrm{mg} / \mathrm{ml})$ and the highest concentration of 2,2',4,4'-tetrabromodiphenyl ether (BDE-47) $(0.0000858 \mathrm{mg} / \mathrm{ml})$. It is important to gain a better understanding of how POPs can interact with GRs as the disruption of glucocorticoid action is thought to contribute to complex diseases.

Key Words: analysis. 
Persistent organic pollutants (POPs) are toxic organic substances that are highly resistant to environmental degradation, bio-accumulate and have long-range atmospheric transport potential (UNEP 2001). This group of environmental chemicals have been detected in human adipose tissue, serum and breast milk samples collected in Asia, Europe, North America and the Arctic (Bi et al. 2006; Pereg et al. 2003; Sjödin et al. 1999; Sjödin et al. 2008) due to their lipophilic nature and resistance to degradation (de Wit et al. 2004). The high lipid solubility of POPs enables them to pass through biological barriers, such as the placental (Beesoon et al. 2011; Inoue et al. 2004; Ode et al. 2013) and blood-brain barriers. A large number of POPs have been shown to be endocrine disrupting chemicals (EDCs) in animals and humans which alters hormone-mediated responses (Birnbaum and Staskal 2004; Boas et al. 2006; Darnerud 2003; Schantz and Widholm 2001; Zoeller 2005). The majority of studies have focused on endocrine disruption of the sex steroid hormones and so have overlooked the disruption to glucocorticoid hormones.

Induction of the hypothalamic-pituitary-adrenal (HPA) axis occurs when individuals are faced with a stressful situation. The hypothalamus will secrete corticotropin-releasing hormone (CRH), which causes the release of adrenocorticotropic hormone (ACTH) from the anterior pituitary gland in the brain to stimulate the release of cortisol from the adrenals. The glucocorticoids, cortisol in humans and corticosterone in rodents, are central to the regulation of many physiological processes including the control of energy metabolism and the modulation of the immune system (Charmandari et al. 2005; Sapolsky et al. 2000). The release of glucocorticoids alters the individuals physiological state in response to environmental conditions (Ricklefs and Wikelski 2002; Wingfield and Sapolsky 2003). Physiological changes shift energy investment away from reproduction and redirect it towards survival (Wingfield and Sapolsky 2003). Glucocorticoids are therefore extremely important to survival and have been strongly associated with fitness traits such as breeding success and individual quality (Angelier et al. 2009, Angelier et al. 2010; Bókony et al. 2009; Goutte et al. 2011). Glucocorticoids, in addition, also play important roles in the process of immunomodulation (Jondal et al. 2004). Despite the importance of glucocorticoids for the regulation of physiological processes, the relationship between environmental chemicals and potential disruption of the HPA axis has not been extensively studied (Odermatt et al. 2006).

Glucocorticoids are lipophilic and can cross the blood-brain barrier where they bind to glucocorticoid receptors (GRs). In humans, the hippocampus and frontal lobes of the brain contain GRs. These are parts of the brain that are involved in cognitive functions such as memory and emotional maladjustments including impulsivity. Changes in the function of the HPA-axis may lead to altered stress responses and changes in cognitive functions. Glucocorticoids are responsible for maturation of tissues essential for neonatal survival (Langlois et al. 2002), therefore disruption of 
normal HPA axis activity may have widespread consequences. In humans, elevated cortisol and aldosterone levels are associated with low birth weight (Martinez-Aguayo et al. 2011). Lanoix and Plusquellec (2013) suggested that a disruption of the stress system could explain an association between environmental contaminants and mental health, especially in children and elderly people.

In contrast to the human estrogen and androgen receptors that are mainly expressed in the gonads, the human GR is expressed in every cell type (Akner et al. 1994). GR disruption has the potential to affect numerous processes. In stressful situations, when levels of glucocorticoids are high, GR activation is necessary for the HPA feedback regulation (de Kloet et al. 1998). GR deficient mice have a range of abnormalities including hyper activation of the HPA axis, impaired lung function and die shortly after birth (Cole et al. 1995). Hyper activation of the HPA axis is expected if GR signalling is disrupted as the HPA axis is subject to feedback inhibition from circulating glucocorticoids which act through GRs (Keller-Wood and Dallman 1984). Hyper activation of the HPA axis is associated with psychiatric disorders including anorexia nervosa, obsessive-compulsive disorder and anxiety. Furthermore, glucocorticoid-mediated feedback inhibition is impaired in people who suffer from depression (Juruena et al. 2003). Hyperactivation of the HPA axis has also been associated with hyperthyroidism (Tsigos and Chrousos 2002). Patients with excessive levels of corticosteroids are at a higher risk of developing cardiovascular disease (Pimenta et al. 2012). Disruption of glucocorticoid signalling could also have implications for obesity, as this system is central to adipocyte differentiation. EDCs have been found to promote adipogenesis in the 3T3-L1 cell line through the activation of the GR, thus leading to obesity (Sargis et al. 2009).

POPs have been linked to GR disruption. Methylsulfonyl metabolites from PCBs have been found to act as GR antagonists (Johansson et al. 1998). POPs can also disrupt regulation of adrenal hormone secretion and function at different levels of the HPA axis. The human H295R adrenal cell model highlighted that the adrenal cortex is a potential target for perfluorononanoic acid (PFNA) (Kraugerud et al. 2011), polychlorinated biphenyls (PCBs) (Li \& Wang 2005; Xu et al. 2006) and polybrominated diphenyl ethers (PBDEs) (Song et al. 2008). POPs can also decrease adrenal hormone production; as has been observed for the organohalogen pesticide $\mathrm{\gamma}-\mathrm{HCH}$ (Lindane) (Oskarsson et al. 2006; Ullerås et al. 2008). Methylsulfonyl metabolites of dichlorodiphenyldichloroethylene (DDE) caused a decrease in H295R cell viability (Asp et al. 2010). Furthermore reduced plasma corticosterone levels were recorded in vivo in suckling mice following administration of these DDE metabolites to their lactating mothers (Jönsson et al. 1993). In arctic birds, high baseline corticosterone concentrations and a reduced stress response have been associated with high concentrations of organochlorines, PBDEs and their metabolites in blood plasma (Verboven et al. 2010). Reduced 
responsiveness of the HPA axis has been demonstrated in amphibians (Gendron et al. 1997) and birds (Mayne et al. 2004) and this has been associated with exposure to POPs.

This study aimed to assess the interaction of individual POPs and their mixtures at the GR level and to see if they disrupted this nuclear receptor's transcriptional activity. Two in vitro bioassays were used; a high content GR redistribution assay (RA) and a GR reporter gene assay (RGA). The GR RA was used as a screening method for the POP mixtures as it measures GR translocation and would therefore presumably detect any GR activity, agonism or antagonism. The GR RGA uses a human mammary gland cell line, with natural steroid hormone receptors for glucocorticoids and progestogens, which has been transformed with a luciferase gene (Willemsen et al. 2004), thereby allowing endocrine disruption at the level of nuclear receptor transcriptional activity to be identified. Disruption of GR activity is important and can have significant implications on health however the interaction of individual POPs and their mixtures with GRs has not been extensively studied.

\section{Materials and methods}

\subsection{Chemicals}

All PBDEs, PCBs and other organochlorines were originally purchased from Chiron As (Trondheim, Norway) and all perfluorinated compounds (PFCs) were obtained from Sigma-Aldrich, St. Louis, MO, USA except perfluorohexanesulfonic acid (PFHxS) which was obtained from Santa Cruz (Dallas, US). Hexabromocyclododecane (HBCD), phosphate buffered saline (PBS), dimethyl sulfoxide (DMSO), thiazolyl blue tetrazolium bromide (MTT) and the steroid hormone cortisol were obtained from Sigma-Aldrich (Dorset, UK). Hoechst nuclear stain was purchased from Perbio (Northumberland, England). Cell culture reagents were supplied by Life Technologies (Paisley, UK) unless otherwise stated. All other reagents were standard laboratory grade.

\subsection{Mixtures}

Mixtures of the test POPs were designed and premade by the Norwegian University of Life Sciences, Oslo. Seven mixtures were used in the assays: (1) total mixture, containing all the test compounds, (2) perfluorinated mixture (PFC), (3) brominated mixture (Br), (4) chlorinated mixture (Cl), (5) perfluorinated and brominated mixture (PFC $+\mathrm{Br}),(6)$ perfluorinated and chlorinated mixture (PFC + $\mathrm{Cl})$ and $(7)$ brominated and chlorinated mixture $(\mathrm{Br}+\mathrm{Cl})$. The chemicals included in the mixtures and their respective concentrations in the stock solution are shown in Table 1 (Berntsen et al. 2015). The concentration of the working stocks for the individual POPs is also shown in Table 1; individual intermediate stocks were prepared of each POP $(1 / 2,1 / 10$ and $1 / 20$ dilutions of the working stocks). 
138 The POP mixtures used in this study were based on concentrations of relevant POPs as measured in 139 human blood and breast milk, according to recent studies of the Scandinavian population (Haug et al. 140 2010, Knutsen et al. 2008; Polder et al. 2008; Polder et al. 2009; Van Oostdam et al. 2004) as described 141 in Berntsen et al. (2015). The compounds were mixed in concentration ratios relevant to human 142 exposure. The stocks of the total mixture, $\mathrm{Cl}$ mixture and the $\mathrm{Cl}$ sub-mixtures were ten times more 143 diluted compared to the PFC and the Br mixtures, and the combined PFC and Br mixture. 
Table 1. The composition and concentrations of original stocks supplied by the Norwegian University of Life Sciences, Oslo. Mixtures: the estimated concentration of POPs in Total, $\mathrm{Cl}, \mathrm{PFC}+\mathrm{Cl}$ and $\mathrm{Br}+\mathrm{Cl}$ stock solutions is 1000000 times estimated concentration in human serum. In comparison to $\mathrm{PFC}, \mathrm{Br}$ and PFC $+\mathrm{Br}$ estimated concentration of POPs is 10000000 times estimated concentration in human serum. For the individual POPs the concentration of each working stock is shown. Intermediate stocks were prepared from the working stocks $(1 / 2,1 / 10$ and $1 / 20$ dilutions). The final concentrations that the cells were exposed to ( $0.2 \%$ DMSO in media) was $1 / 1000,1 / 2000,1 / 10000$ and $1 / 20000$ of the original working stocks. For the individual compounds the cells were exposed to 500, 1000, 5000 and 10000 times serum level).

\begin{tabular}{|c|c|c|c|c|c|c|c|c|}
\hline \multirow[b]{2}{*}{ Perfluorinated compounds (PFCs) } & \multicolumn{7}{|c|}{ Mixture Stock Concentration $(\mathrm{mg} / \mathrm{ml})$} & \multirow{2}{*}{$\begin{array}{c}\text { Individual } \\
\text { Stock } \\
\text { Concentration } \\
(\mathrm{mg} / \mathrm{ml})\end{array}$} \\
\hline & Total & PFC & $\mathrm{Br}$ & $\mathrm{Cl}$ & $\mathrm{PFC}+\mathrm{Br}$ & $\mathrm{PFC}+\mathrm{Cl}$ & $\mathrm{Br}+\mathrm{Cl}$ & \\
\hline PFOA & 4.523 & 45.225 & & & 45.225 & 4.523 & & 45.225 \\
\hline PFOS & 29.425 & 294.250 & & & 294.250 & 29.425 & & 294.250 \\
\hline PFDA & 0.495 & 4.950 & & & 4.950 & 0.495 & & 4.950 \\
\hline PFNA & 0.800 & 8.000 & & & 8.000 & 0.800 & & 8.000 \\
\hline $\mathrm{PFHxS}$ & 3.450 & 34.500 & & & 34.500 & 3.450 & & 34.500 \\
\hline PFUnDA & 0.560 & 5.600 & & & 5.600 & 0.560 & & 5.600 \\
\hline \multicolumn{9}{|c|}{ Polybrominated diphenyl ethers (PBDEs) } \\
\hline BDE-209 & 0.011 & & 0.108 & & 0.108 & & 0.011 & 0.108 \\
\hline BDE-47 & 0.009 & & 0.086 & & 0.086 & & 0.009 & 0.086 \\
\hline BDE-99 & 0.004 & & 0.035 & & 0.035 & & 0.004 & 0.035 \\
\hline BDE-100 & 0.002 & & 0.022 & & 0.022 & & 0.002 & 0.022 \\
\hline BDE-153 & 0.001 & & 0.010 & & 0.010 & & 0.001 & 0.010 \\
\hline BDE-154 & 0.002 & & 0.018 & & 0.018 & & 0.002 & 0.018 \\
\hline $\mathrm{HBCD}$ & 0.025 & & 0.246 & & 0.246 & & 0.025 & 0.246 \\
\hline \multicolumn{9}{|l|}{ Polychlorinated biphenyls (PCBs) } \\
\hline PCB 138 & 0.222 & & & 0.222 & & 0.222 & 0.222 & 2.220 \\
\hline PCB 153 & 0.362 & & & 0.362 & & 0.362 & 0.362 & 3.620 \\
\hline PCB 101 & 0.008 & & & 0.008 & & 0.008 & 0.008 & 0.078 \\
\hline PCB 180 & 0.194 & & & 0.194 & & 0.194 & 0.194 & 1.940 \\
\hline PCB 52 & 0.010 & & & 0.010 & & 0.010 & 0.010 & 0.096 \\
\hline РCB 28 & 0.013 & & & 0.013 & & 0.013 & 0.013 & 0.128 \\
\hline PCB 118 & 0.064 & & & 0.064 & & 0.064 & 0.064 & 0.640 \\
\hline \multicolumn{9}{|l|}{ Other organochlorines } \\
\hline$p, p^{\prime}-\mathrm{DDE}$ & 0.502 & & & 0.502 & & 0.502 & 0.502 & 5.020 \\
\hline $\mathrm{HCB}$ & 0.117 & & & 0.117 & & 0.117 & 0.117 & 1.170 \\
\hline$\alpha$ - chlordane & 0.011 & & & 0.011 & & 0.011 & 0.011 & 0.108 \\
\hline oxy - chlordane & 0.022 & & & 0.022 & & 0.022 & 0.022 & 0.222 \\
\hline trans-nonachlor & 0.041 & & & 0.041 & & 0.041 & 0.041 & 0.408 \\
\hline$\alpha-\mathrm{HCH}$ & 0.006 & & & 0.006 & & 0.006 & 0.006 & 0.060 \\
\hline$\beta-\mathrm{HCH}$ & 0.053 & & & 0.053 & & 0.053 & 0.053 & 0.526 \\
\hline $\mathrm{Y}-\mathrm{HCH}$ (Lindane) & 0.006 & & & 0.006 & & 0.006 & 0.006 & 0.060 \\
\hline Dieldrin & 0.024 & & & 0.024 & & 0.024 & 0.024 & 0.240 \\
\hline
\end{tabular}


Recombinant U2OS cells stably expressing the human GR (U2OS-GR) were routinely cultured in a humidified atmosphere of $5 \% \mathrm{CO}_{2}$ at $37{ }^{\circ} \mathrm{C}$. Cells were grown in $75 \mathrm{~cm}^{2}$ flasks in Dulbecco's modified eagle medium (DMEM) media supplemented with $10 \%$ foetal bovine serum (FBS), $2 \mathrm{mM}$ L-Glutamine, $1 \%$ penicillin-streptomycin and $0.5 \mathrm{mg} / \mathrm{ml} \mathrm{G} 418$. TrypLE ${ }^{\mathrm{TM}}$ Express trypsin was used to disperse the cells from the flasks, while cell counting and viability checks prior to seeding plates were achieved by trypan blue staining and using a Countess ${ }^{\circledR}$ automated cell counter.

Cells were seeded (using DMEM supplemented with 2mM L-Glutamine, 1\% PenicillinStreptomycin, $0.5 \mathrm{mg} / \mathrm{ml} \mathrm{G} 418$ and $10 \%$ hormone depleted FBS) at a concentration of $6 \times 10^{4}$ cells per well in $100 \mu \mathrm{l}$ of media into black walled 96 well plates with clear flat bottoms (Grenier, Germany). The cells were incubated for $1 \mathrm{~h}$ at room temperature $(\mathrm{RT})\left(20-25^{\circ} \mathrm{C}\right)$ to ensure that they attached evenly within each well. The cells were then incubated for $24 \mathrm{~h}$ at $37^{\circ} \mathrm{C}$, and subsequently exposed in assay media (DMEM supplemented with $2 \mathrm{mM} \mathrm{L-Glutamine} \mathrm{and} \mathrm{1 \%} \mathrm{Penicillin-Streptomycin)} \mathrm{to} \mathrm{1/1000,}$ $1 / 2000,1 / 10000$ and $1 / 20000$ dilutions ( $0.2 \%$ DMSO in media) of the original stocks, which corresponded to $10000,5000,1000$ and 500 times the levels in serum for the PFC, Br and PFC $\mathrm{Br}$ mixtures. For the remaining mixtures (total, $\mathrm{Cl}, \mathrm{PFC}+\mathrm{Cl}$ and $\mathrm{Br}+\mathrm{Cl}$ ) the exposures corresponded to $1000,500,100$ and 50 times the levels in serum. Assay media was used to dilute the stock solutions. The cortisol standard curve used covered the range of $0.02-22.7 \mathrm{ng} / \mathrm{ml}$. A solvent control $0.2 \% \mathrm{v}: \mathrm{v}$ DMSO in media was also added to each plate. The cells were incubated for $48 \mathrm{~h}$ after which the media was discarded and the cells fixed by adding $150 \mu$ fixing solution (10\% formalin, neutral-buffered solution) per well. The plate was incubated at RT for $20 \mathrm{~min}$. The fixing solution was then removed and cells washed four times with $200 \mu \mathrm{l}$ PBS. After the last wash was removed and $100 \mu \mathrm{l}$ of $1 \mu \mathrm{M}$ Hoechst Staining Solution ( $1 \mu \mathrm{M}$ Hoechst in PBS containing 0.5\% Triton X-100) was added to each well before the plate was sealed with a black plate sealer and left at least $30 \mathrm{~min}$ before imaging.

\subsection{High content analysis (HCA)}

The GR RA was imaged using a Celllnsight ${ }^{T M}$ NXT High Content Screening (HCS) platform (Thermo Fisher Scientific, UK). This instrument analyses epifluorescence of individual cell events using an automated micro-plate reader analyser interfaced with a PC (Dell precision 136 T5600 workstation). Hoechst dye was used to measure nuclear morphology: cell number $(\mathrm{CN})$, nuclear intensity $(\mathrm{NI})$ and nuclear area (NA). Data was captured for each plate at 10x objective magnification in the selected excitation and emission wavelengths for Hoechst dye (Ex/Em 350/461 nm) and enhanced Green Fluorescent Protein (GFP) (488/509 nm). Briefly, the U2OS-GR cell line is a recombinant cell line which stably expresses the human GR fused to an enhanced GFP. The expression of the EGFP-GR is controlled by a promoter and continuous expression is maintained by the addition of G418 to the culture media. 
The primary output in the GR RA is the translocation from cytoplasm to nucleus of enhanced GFP-GR. The output used was MEAN_CircRingAvgIntenDiffCh2 (difference in average fluorescence intensities of nucleus and cytoplasm).

\subsection{GR reporter gene assay ( $R G A)$}

The TGRM-Luc cell line for the detection of glucocorticoids and progestogens previously developed by Willemsen et al. (2004) was used. This transformed cell line was cultured in DMEM and 10\% FBS, and grown in $75 \mathrm{~cm}^{2}$ tissue culture flasks (Nunc, Roskilde, Denmark) at $37^{\circ} \mathrm{C}$ with $5 \% \mathrm{CO}_{2}$ and $95 \%$ humidity. TrypLE ${ }^{\mathrm{TM}}$ Express trypsin was used to disperse the cells from the flasks, while cell counting and viability checks prior to seeding plates were achieved by trypan blue staining and using a Countess ${ }^{\circledR}$ automated cell counter. The RGA was carried out in assay media (DMEM supplemented with $10 \%$ hormone depleted serum).

Cells were seeded at a concentration of $4 \times 10^{5} \mathrm{cells} / \mathrm{ml}$ in $100 \mu \mathrm{l}$ media into white walled 96 well plates with clear flat bottoms (Greiner Bio-One, Germany). The cells were incubated for $24 \mathrm{~h}$ and then exposed to four dilutions of each individual compound and mixture for the agonist test (cells were exposed as in section 2.3). For the individual compounds the four dilutions represent 500,1000 , 5000 and 10000 times serum levels. The cortisol standard curve covered the range of $4.5-181.2 \mathrm{ng} / \mathrm{ml}$. A solvent control $0.2 \% \mathrm{v}: \mathrm{v}$ DMSO in media was also added to each plate. Antagonist tests were carried out by incubating the four dilutions of each individual compound and mixture with the positive control $(90.6 \mathrm{ng} / \mathrm{ml}$ cortisol). The cells were incubated for $48 \mathrm{~h}$, after which the media was discarded and the cells were washed twice with PBS. The cells were lysed with $30 \mu \mathrm{l}$ cell culture lysis buffer (Promega, Southampton, UK) $100 \mu$ l luciferase substrate (Promega, Southampton, UK) was injected into each well and the response measured using the Mithras Multimode Reader (Berthold, Other, Germany). The response of the cell line to the various compounds was measured and compared with the solvent and positive controls.

\subsection{Cell viability assay}

As well as visual inspection of the U2OS-GR and TGRM-Luc cells under the microscope to evaluate cell morphology and attachment, the 3-(4,5-dimethylthiazol-2-yl)-2,5 diphenyltetrazolium bromide (MTT) cell viability assay was performed.

The cells were exposed exactly as for the GR RGA (section 2.5 ) after which the percentage of viable cells was determined using the MTT assay. The cells were washed once with PBS before MTT solution ( $50 \mu \mathrm{l}$ of $2 \mathrm{mg} / \mathrm{ml}$ stock in PBS diluted 1:2.5 in assay media) was added to each well and the cells incubated for $3 \mathrm{~h}$. Viable cells convert the soluble yellow MTT to insoluble purple formazan by 
the action of mitochondrial succinate dehydrogenase. The supernatant was removed and $200 \mu \mathrm{l}$ of DMSO was added to dissolve the formazan crystals. The plate was incubated at $37^{\circ} \mathrm{C}$ with agitation for $10 \mathrm{~min}$ before absorbance was measured at $570 \mathrm{~nm}$ with a reference filter at $630 \mathrm{~nm}$ using a microtitre plate reader (TECAN, Switzerland). Viability was calculated as the percentage absorbance of the sample when compared with the absorbance of the solvent control.

\subsection{Statistical analysis}

Exposures were carried out in triplicate wells and experiments were repeated at least twice. Data was analysed using Microsoft Excel 2013 and Graphpad PRISM software version 5.01 (San Diego, CA). All values shown are expressed as mean \pm standard error of the mean (SEM) of the independent exposures. Differences between groups were analysed by one-way ANOVA followed by Dunnett's procedure for multiple comparisons. Significant effects are represented by $p \leq 0.05\left({ }^{*}\right), p \leq 0.01(* *)$ and $p \leq 0.001(* * *)$.

\section{Results and discussion}

\subsection{Cell viability of TGRM-Luc cell line after exposure to individual POPs}

The MTT assay evaluates cytotoxicity by measurement of mitochondrial metabolic activity. As the individual POPs were tested for GR activity using the RGA only, their toxicity was evaluated on the TGRM-Luc cell line only using the MTT assay (statistically significant results are shown in Figure 1).

PFCs are widely reported to be cytotoxic, particularly PFOS which has been shown to affect the viability of numerous cell culture systems including: human hepatocarcinoma cells (HepG2) (Florentin et al. 2011; Shabalina et al. 1999), human placental syncytiotrophoblasts (Zhang et al. 2015), neonatal Sertoli cells/gonocytes (Zhang et al. 2013) and neural stem cells (Wan Ibrahim et al. 2013). These studies support the finding that PFOS in the present study (at the two highest concentrations; $0.147 \mathrm{mg} / \mathrm{ml}$ and $0.294 \mathrm{mg} / \mathrm{ml}$ corresponding to 5000 and 10000 times serum level respectively) significantly decreased TGRM-Luc cell viability to $42.8 \%$ and $3.8 \%(p \leq 0.001)$ (Figure $1 \mathrm{~A})$. Conversely, other studies have found that PFOS has no effect on cell viability in MCF-7 (Maras et al. 2006) and human adrenocortical H295R cells (Kraugerud et al. 2011). As both Maras et al. (2006) and Kraugerud et al. (2011) used similar concentrations of PFOS to the present study the differences observed may show that PFOS is more cytotoxic to particular cell lines.

Perfluorooctanoic acid (PFOA) and PFOS use has been regulated worldwide. Perfluoroundecanoic acid (PFUnDA), a PFOA homologue, is sometimes used as an alternative to PFOA 
(EPA 2013). PFUnDA has been less extensively studied than PFOS or PFOA, however as PFCs with longer carbon chains tend to be more persistent (Hirata-Koizumi et al. 2012) the toxicological potential of PFUnDA could be of concern. In the current study, viability of TGRM-Luc cells significantly increased after exposure to the highest concentration $(0.0056 \mathrm{mg} / \mathrm{ml} ; 10000$ times serum level) of PFUnDA to $117.9 \%(p \leq 0.01)$ (Figure 1B). The MTT assay relies on mitochondrial dehydrogenases of living cells to cause a conversion of the coloured formazan salt (Slater et al. 1963). Actively proliferating cells increase their metabolic activity while cells exposed to toxins may have decreased activity. Alternatively, the apparent stimulatory effect seen in the MTT assay for some of the POPs, could be as a consequence of cell protection or adaptive response to toxin exposure (Ruiz et al. 2006)

From the PCB group, no significant effects on cell viability were evident apart from PCB 153 (at the highest concentration; $0.0036 \mathrm{mg} / \mathrm{ml}$ ), which significantly increased TGRM-Luc cell viability to $123.1 \%$ ( $p \leq 0.05$ ) (Figure 1C). PCB-153 has previously been seen to induce cell proliferation in in vivo experiments on rats (Lu et al. 2003). A commercial PCB mixture, Aroclor 1260, has been shown to induce hepatocyte proliferation in rodents (Whysner and Wang 2001). In contrast, PCB-153 significantly induced loss of cell viability in human liver and kidney cell cultures in a concentration and time-dependent manner in a study by Ghosh et al. (2010). Furthermore, PCB 153 has been found to lower cell viability in neonatal Sertoli cell/gonocytes (Zhang et al. 2013). The reason for the observed differences between these studies and the present study could be because Ghosh et al. (2010) tested PCB 153 at a higher concentration $(0.025 \mathrm{mg} / \mathrm{ml})$ in comparison to the present study (the highest concentration tested was $0.0036 \mathrm{mg} / \mathrm{ml}$ ). Zhang et al. (2013) found significant decreases in cell viability when using the same concentration as the present study $(0.0036 \mathrm{mg} / \mathrm{ml})$ however the cell culture systems used were different.

The toxicity of PBDEs has been widely reported in several cell culture systems, such as rat cerebellar granule cells (Reistad et al. 2006), human astrocytoma cells (Madia et al. 2004), hippocampal neurons, human neuroblastoma cells, human foetal liver hematopoietic cells (He et al. 2008, He et al. 2009; Shao et al. 2008) and HepG2 cells (Hu et al. 2007). In the present study only one PBDE, BDE-153, decreased cell viability. Exposure to BDE-153 at $0.0000098 \mathrm{mg} / \mathrm{ml}$ (the highest concentration; 10000 times serum level); reduced viability to $93.3 \%$ ( $p \leq 0.05)$ (Figure 1D). Importantly, these studies tested the PBDEs at much higher concentrations than the TGRM-Luc cell line was exposed to. Schreiber et al. (2010) tested concentrations of BDE-47 and BDE-99 that were comparable to the present study $(0.1-10 \mu \mathrm{M}$; BDE-47 range $48.5-4857.9 \mathrm{ng} / \mathrm{ml}$; BDE-99 range $56.5-5646.9$ $\mathrm{ng} / \mathrm{ml}$ ) in human neural progenitor cells and found no cytotoxicity. This is supported by the present study which found no significant cytotoxicity for either BDE-47 or BDE-99 at any concentration tested (range covered was $4.2-85.7 \mathrm{ng} / \mathrm{ml}$ for BDE-47 and $1.7-35.2 \mathrm{ng} / \mathrm{ml}$ for BDE-99). 
From the group of other organochlorines, two compounds significantly impacted cell viability.

294 Alpha-chlordane ( $\alpha$-chlordane), at the highest concentration $(0.000108 \mathrm{mg} / \mathrm{ml})$, increased TGRM-Luc 295 cell viability to $121.8 \%$ ( $p \leq 0.05$ ) (Figure $1 E$ ). This compound has been found to cause increased cell 296 proliferation in the thyroid gland and promote liver tumours in mice (Barrass et al. 1993). Conversely, 297 suppression of lymphocyte proliferation after $\alpha$-chlordane exposure has been recorded (Chuang et al. 298 1992). The second compound that significantly affected TGRM-Luc cell viability in the present study 299 was $\gamma-\mathrm{HCH}$. Exposure to the highest concentration of $\mathrm{\gamma}-\mathrm{HCH}(0.00006 \mathrm{mg} / \mathrm{ml})$ decreased cell viability 300 to $92.2 \%(p \leq 0.05$ ) (Figure 1F). $y-\mathrm{HCH}$ has similar effects on the viability of MCF-7 cells (Joseph and D'Auvergne 2012) with exposure to $0.06 \mathrm{mg} / \mathrm{ml}$ significantly decreasing cell viability. 
A

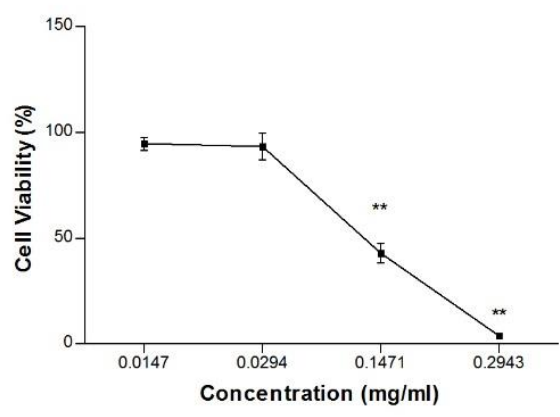

C
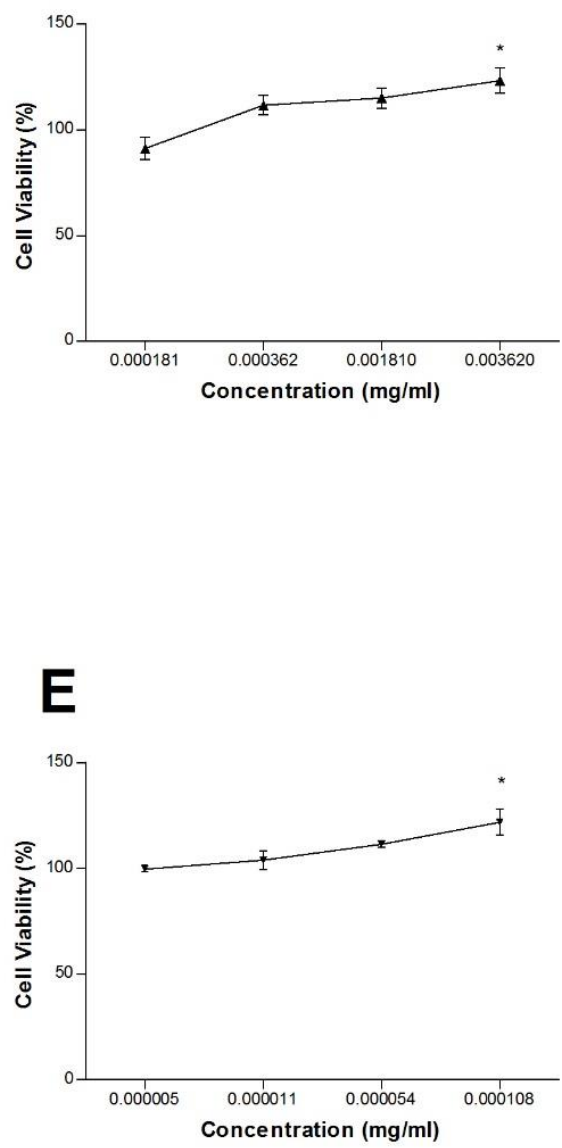

B

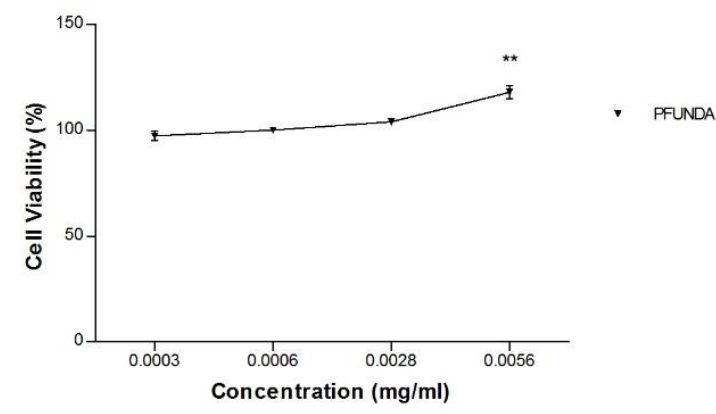

D

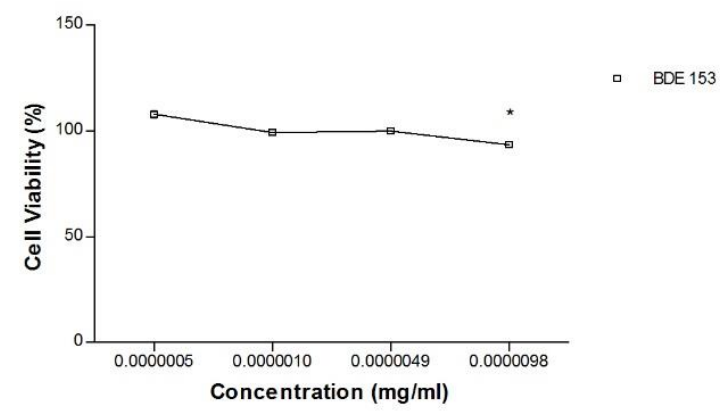

F

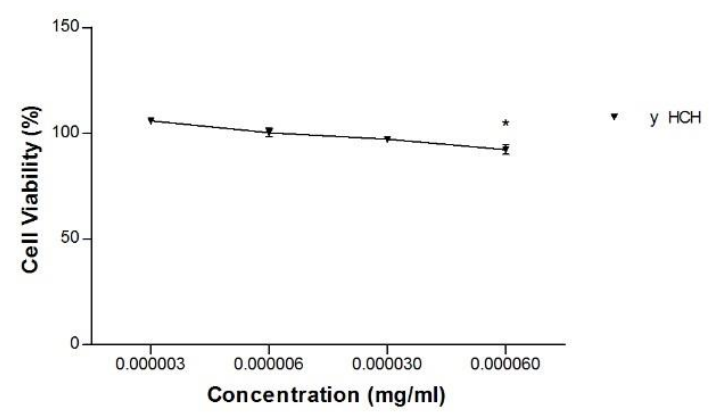

Figure 1: Viability of the TGRM-Luc cell line following exposure to individual POPs: (A) PFOS,(B) PFUNDA, (C) PCB 153, (D) BDE-153, (E) Alpha-Chlor and (F) $\mathrm{Y}-\mathrm{HCH}$; measured using the MTT Assay. Values are mean \pm SEM $n=2 p \leq 0.05(*), p \leq 0.01\left(^{* *}\right)$ and $p \leq 0.001\left({ }^{* *}\right)$ represent significant cytotoxic effects. Only compounds which have significant results are shown. The concentrations shown are equivalent to 500, 1000, 5000 and 10000 times serum level).

\subsection{Cell viability of TGRM-Luc and U2OS-GR cell lines after exposure to POP mixtures}


310 The MTT assay was also used to determine the viability of TGRM-Luc cells (used in the RGA) and the

311 U2OS-GR cells (used in the HCA assay) following exposure to different concentrations of test mixtures 312 (Figure 2).

313 The PFC mixture (at 5000 and 10000 times serum levels) decreased cell viability to $19.5 \%$ and 314 12.4\% respectively (U2OS-GR cell line) and 14.6\% and 4.3\% respectively (TGRM-Luc cell line) (Figure 315 2B); implying that this mixture is more toxic to the TGRM-Luc cells. The toxicity in the PFC mixture is 316 likely to be from PFOS as none of the other compounds in the PFC mixture were cytotoxic to the TGRM317 Luc cell line (section 3.1). The PFC $+\mathrm{Br}$ mixture (at 5000 and 10000 times serum levels) also decreased 318 cell viability to $11.2 \%$ and $9.4 \%$ respectively (U2OS-GR) and $28.4 \%$ and $6.7 \%$ respectively (TGRM-Luc) 319 (Figure 2E). In the PFC + Br mixture the toxicity to the TGRM-Luc cell line is again likely to be from PFOS 320 (section 3.1). No significant cytotoxicity was evident for the total, $\mathrm{Br}, \mathrm{Cl}, \mathrm{PFC}+\mathrm{Cl}$ or $\mathrm{Br}+\mathrm{Cl}$ mixtures at 321 any concentration in either cell line (Figure 2A, C, D, F and G). However, exposure to the $\mathrm{Cl}$ mixture 322 produced small, but statistically significant increases in cell viability of $109.4 \%$ and $108.0 \%$, at 100 and 323500 times serum level respectively, in the U2OS-GR cell line ( $p \leq 0.05$ for both) (Figure 2D). 
A

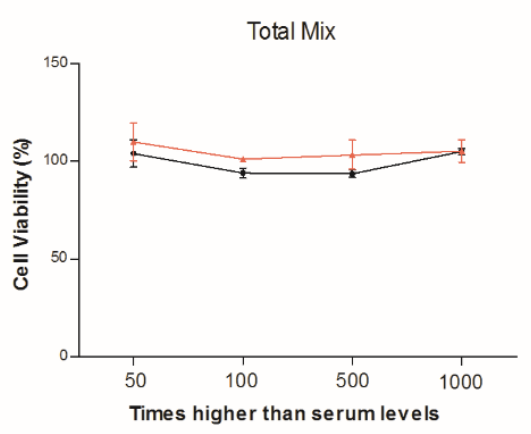

C

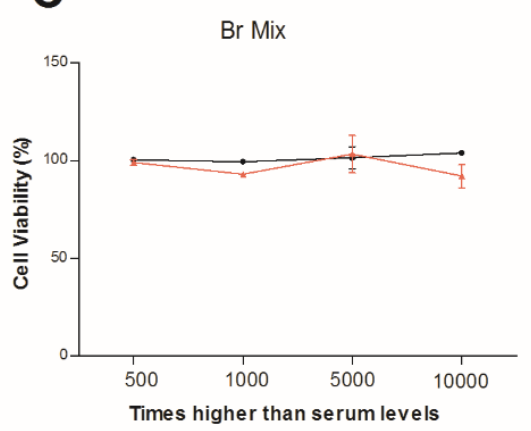

E

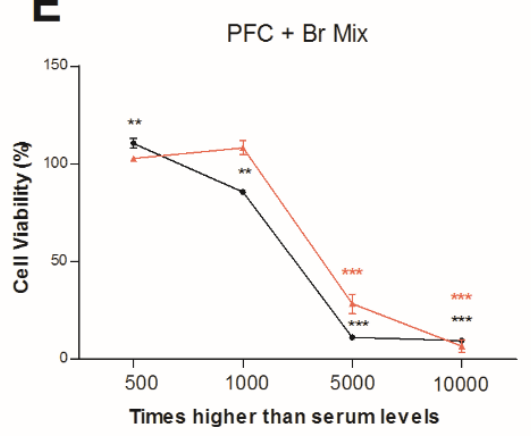

G $\quad \mathrm{Br}_{\mathrm{r}}+\mathrm{Cl}$ Mix

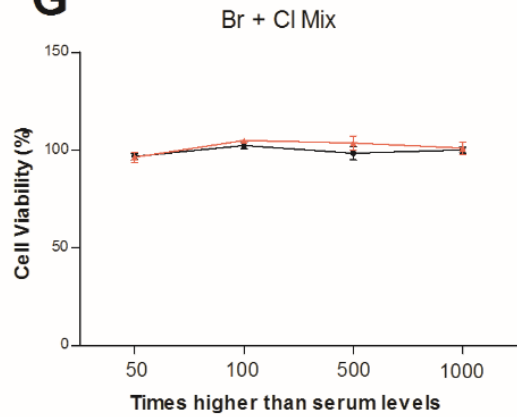

B

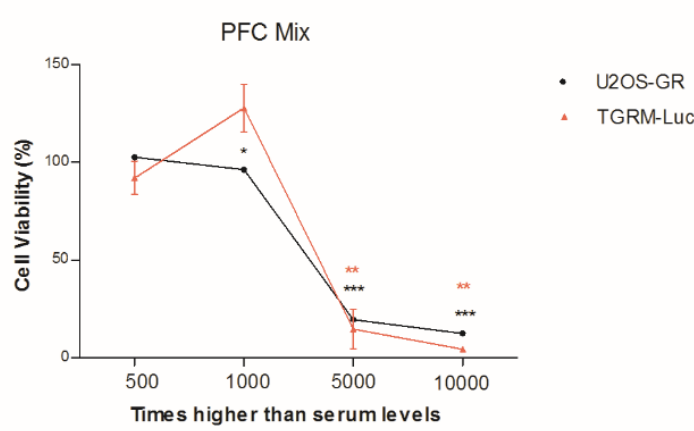

D
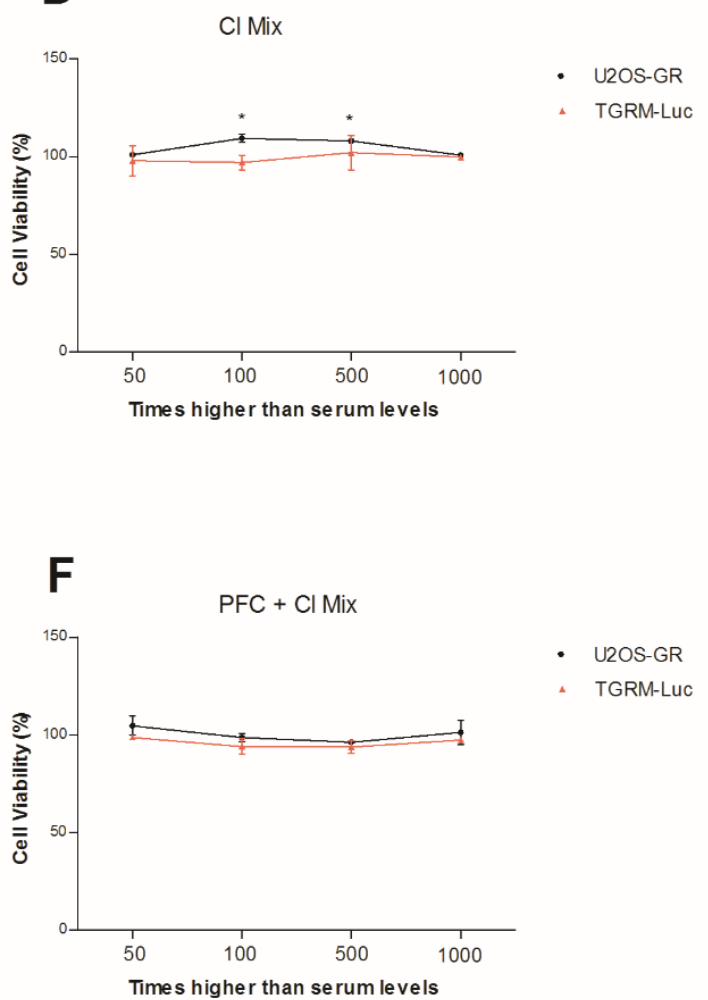

Figure 2: Viability of the TGRM-Luc and U2OS-GR cell lines following exposure to different mixtures of POPs; measured using the MTT Assay. Values are mean \pm SEM $n=2 p \leq 0.05\left({ }^{*}\right), p \leq 0.01\left({ }^{* *}\right)$ and $p \leq$ $0.001(* * *)$ represent significant cytotoxic effects. 
The HCA GR RA allows CN, NA and NI to be measured and these can be used as indicators of cytotoxicity. Significant effects were evident for CN, NA and NI which indicated cytotoxicity (Figure 3). $\mathrm{CN}$ for the second highest concentration (5000 times serum level) of the PFC mixture was significantly decreased to $16.7 \%$ ( $p \leq 0.01$ ) For the highest concentration of PFC mixture (10000 times serum level), cell viability decreased to $61.9 \%$ however it was not deemed statistically significant ( $p \geq 0.05)$. The two highest concentrations of the PFC $+\mathrm{Br}$ mixture (5000 and 10000 times serum level) decreased CN to $37.0 \%$ and $18.4 \%$ respectively ( $p \leq 0.001$ ) (Figure $3 A$ ). NA was significantly decreased in U2OS-GR cells after exposure to the highest concentration of the $\mathrm{Cl}$ mixture (92.0\%, $p \leq 0.01$; Figure 3B). Similarly, $\mathrm{NA}$ was decreased after exposure to the $\mathrm{Br}+\mathrm{Cl}$ mixture at 100 and 500 times serum level $(93.4 \%$ and $91.7 \%$ respectively, $p \leq 0.05$; Figure $3 \mathrm{~B})$. Nuclear shrinkage is a hallmark of apoptosis. However as there were no significant decreases in $\mathrm{CN}$ for either the $\mathrm{Cl}$ or $\mathrm{Br}+\mathrm{Cl}$ mixtures the decrease in NA did not result in significant cell death. $\mathrm{NI}$ was decreased after exposure to the highest concentrations (5000 and 10000 times serum level) of the PFC mixture (66.4\% and $17.5 \%$ respectively $p \leq 0.01$ for both) and the PFC $+\mathrm{Br}$ mixture (10000 times serum level), 28.3\% ( $p \leq 0.001)$ (Figure $3 \mathrm{C}$ ). The swelling of nuclei is linked to compound induced necrosis and $\mathrm{NI}$ correlates to nuclear size with large nuclei showing lower intensities (Mirochnitchenko et al. 1999); as NI and CN were significantly decreased for both the PFC and PFC + Br mixtures it is likely that these mixtures caused the U2OS-GR cells to undergo necrosis. Additionally, $\mathrm{NI}$ was also decreased for all concentrations of the $\mathrm{Br}+\mathrm{Cl}$ mixture (apart from the most concentrated), $92.0 \%, 91.3 \%$ and $89.5 \%$ ( $p \leq 0.05,0.05,0.01$ respectively; Figure 3D). $\mathrm{The} \mathrm{Br}$ $+\mathrm{Cl}$ mixture may be causing the U2OS-GR cells to start to undergo necrosis however there was no significant change in $\mathrm{CN}$.

In summary, there was reasonable agreement between the MTT assay results and the CN HCA parameter (Table 2) with the two highest concentrations of both the PFC and PFC $+\mathrm{Br}$ mixtures being highlighted as decreased in both; all were statistically significant apart from CN for the PFC mixture at 10000 times serum level. However the MTT assay also highlighted decreased cell viability after exposure to the PFC mixture (1000 times serum level), increased cell viability after exposure to the $\mathrm{Cl}$ mixture (100 and 500 times serum levels), increased cell viability for the PFC $+B r$ mixture (500 times serum level) and decreased exposure at 1000 times serum level for the same mixture; these changes were not detected in any HCA parameter. In contrast, the HCA parameters NA and NI highlighted subtle changes after exposure to the $\mathrm{Br}+\mathrm{Cl}$ mixture; this mixture was not deemed cytotoxic by the MTT assay. In addition the NA parameter was significantly decreased after exposure to the $\mathrm{Cl}$ mixture (1000 times serum level); this was not highlighted by the MTT assay. 
A

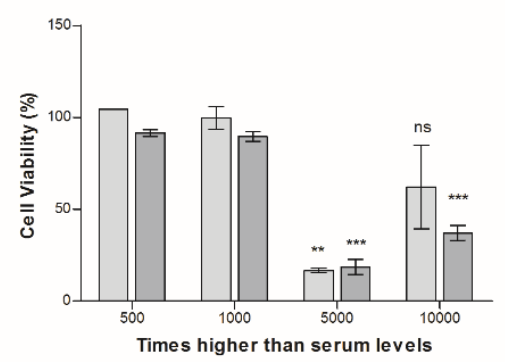

C

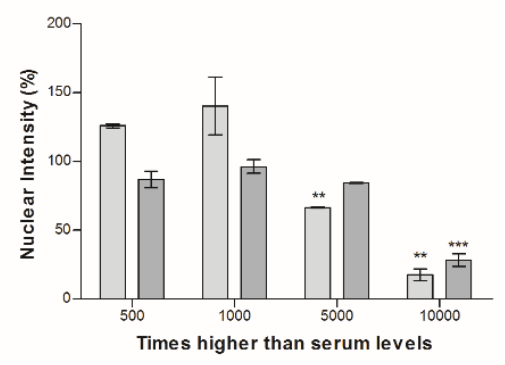

B

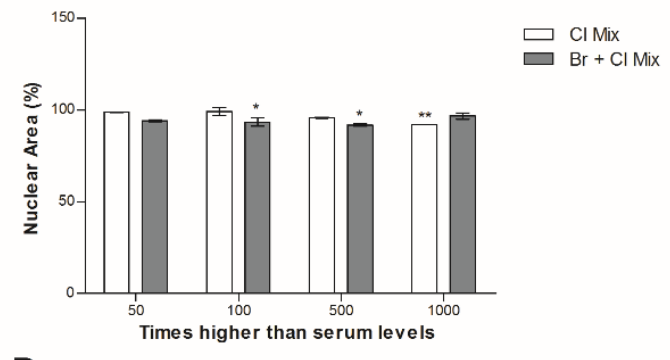

D

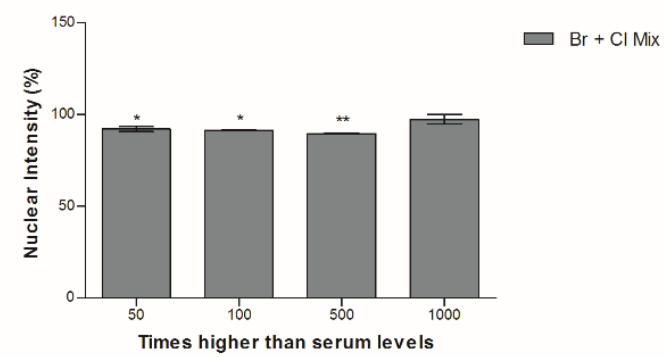

361

Figure 3: Nuclear changes in U2OS-GR cells measured using HCA parameters $\mathrm{CN}, \mathrm{NA}$ and $\mathrm{NI}$ with Hoechst staining. (A) Cell viability as measured by $\mathrm{CN}$ for the PFC and $\mathrm{PFC}+\mathrm{Br}$ mixtures. (B) Nuclear area for the $\mathrm{Cl}$ and $\mathrm{Br}+\mathrm{Cl}$ mixtures. (C) Nuclear intensity for the PFC and PFC $+\mathrm{Br}$ mixtures. (D) Nuclear intensity for $\mathrm{Br}+\mathrm{Cl}$ mixture. Note: only mixtures which had at least one statistically significant effect are shown. Values are mean $\pm \operatorname{SEM~} n=2 p \leq 0.05(*), p \leq 0.01\left({ }^{* *}\right)$ and $p \leq 0.001\left({ }^{* *}\right)$ represent significant cytotoxic effects.

Table 2: Comparison of MTT and HCA nuclear parameter results for U2OS-GR cells. The grey shading indicates that no significant effects were found. The total, $\mathrm{Br}$ and PFC $+\mathrm{Cl}$ mixtures are not shown as toxic effects were not evident in the MTT assay or in HCA parameters. $\uparrow$ indicates increased effect e.g. for the MTT assay it shows increased cell viability. $\downarrow$ indicates decreased effect e.g. for the NA parameter it shows a decrease in nuclear size. Numbers 1-4 in the first column represent the concentration of the mixture; for PFC and PFC + Br it represents 500, 1000, 5000 and 10000 times serum levels. For the $\mathrm{Cl}$ and $\mathrm{Br}+\mathrm{Cl}$ mixtures it represents $50,100,500$ and 1000 . Statistical significance is also indicated: $p \leq 0.05\left({ }^{*}\right), p \leq 0.01\left({ }^{* *}\right)$ and $p \leq 0.001\left(^{* * *}\right)$ represent significant cytotoxic effects.

\begin{tabular}{|c|c|c|c|c|c|c|c|c|c|c|c|c|c|c|c|c|}
\hline & \multicolumn{3}{|c|}{ PFC } & \multicolumn{4}{c|}{ PFC + Br } & \multicolumn{5}{c|}{ Cl } & \multicolumn{3}{c|}{ Br + Cl } \\
\hline & MTT & CN & NA & NI & MTT & CN & NA & NI & MTT & CN & NA & NI & MTT & CN & NA & NI \\
\hline 1 & & & & & $\uparrow^{* *}$ & & & & & & & & & & & $\downarrow^{*}$ \\
\hline 2 & $\downarrow^{*}$ & & & & $\downarrow^{* *}$ & & & & $\uparrow^{*}$ & & & & & & $\downarrow^{*}$ & $\downarrow^{*}$ \\
\hline 3 & $\downarrow^{* * *}$ & $\downarrow^{* *}$ & & & $\downarrow^{* * *}$ & $\downarrow^{* * *}$ & & & $\uparrow^{*}$ & & & & & & $\downarrow^{*}$ & $\downarrow^{* *}$ \\
\hline 4 & $\downarrow^{* * *}$ & $\downarrow^{\text {ns }}$ & & $\downarrow^{* *}$ & $\downarrow^{* *}$ & $\downarrow^{* * *}$ & & $\downarrow^{* * *}$ & & & $\downarrow^{* *}$ & & & & & \\
\hline
\end{tabular}

\subsection{GR HCA Redistribution Assay}

The GR RA was used to screen the POP mixtures for GR translocation. Glucocorticoids exert their activity through binding to GR which results in either activation or repression of a large set of 
glucocorticoid responsive genes. In the inactive state, the GR is located in the cytoplasm (Figure 4A) bound to various heat-shock proteins in a large multi-protein complex (Pratt and Toft 1997). When activated by ligand binding, the GR detaches from the complex, translocates to the nucleus (Figure $4 B$ ) where it interacts with GR regulatory elements (GREs) to stimulate transcription and act as a transcription factor to regulate the expression of its target genes (John et al. 2008). In the GR RA, the translocation of a GFP-GR fusion protein from the cytoplasm to the nucleus is measured; both GR agonists and antagonists induce nuclear translocation (Rosenfeld and Glass 2001). No significant GR translocation effects were found for any of the POP mixtures at any concentration.

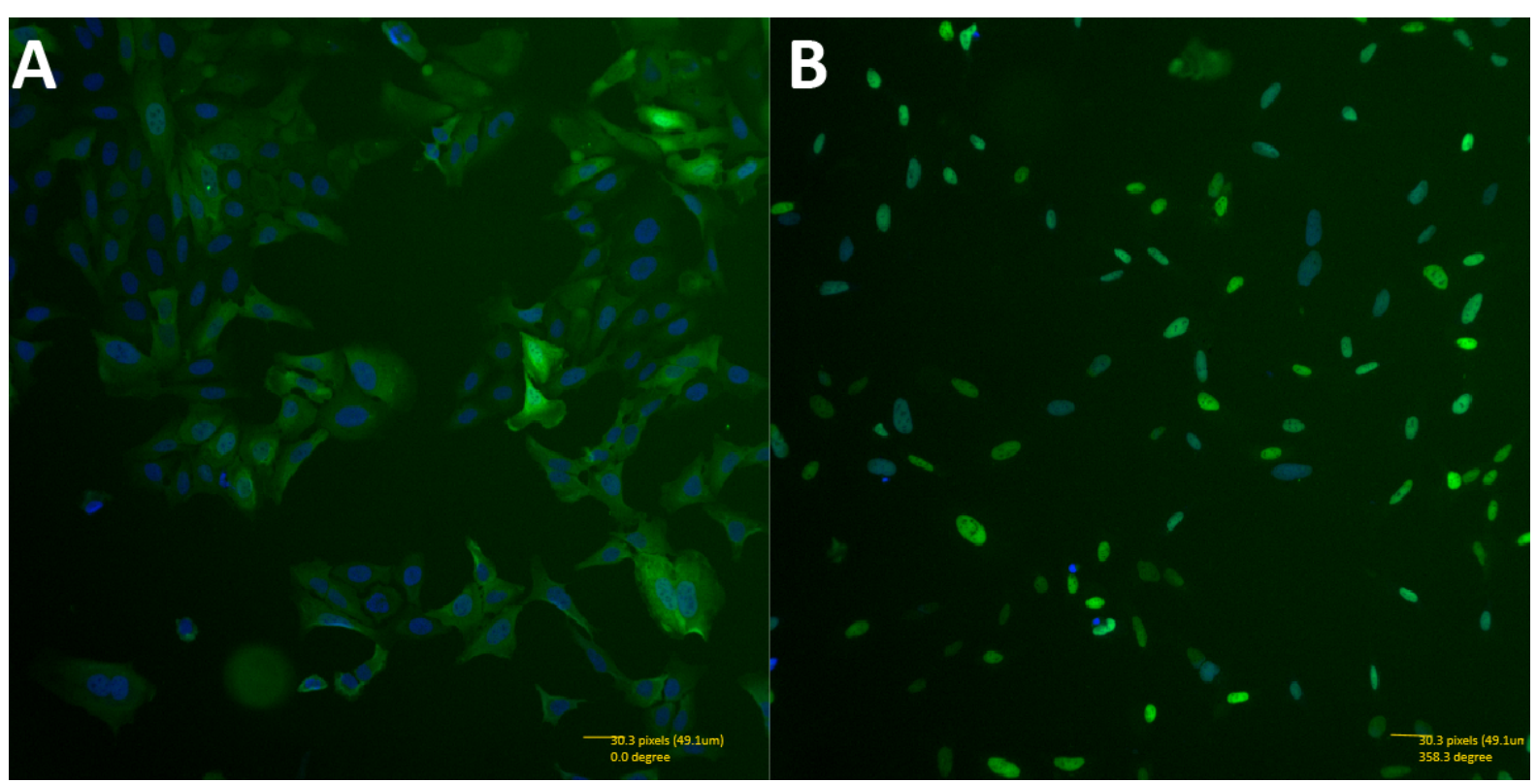

Figure 4: Example of GR RA images: (A) negative control - DMSO (B) positive control - $11.4 \mathrm{ng} / \mathrm{ml}$ cortisol. In the inactive state, the GR (images show this receptor tagged with enhanced GFP) is found in the cytoplasm in complex with heat shock proteins. Upon ligand binding, the GR translocates to the nucleus, dimerizes, and acts as a transcription factor to regulate the expression of its target genes. (Blue stain is Hoechst nuclear stain).

\subsection{GR reporter gene assay}

RGAs utilise the ability of steroid hormones to bind their specific receptor and to induce (or, for antagonists, repress) a bioluminescent cellular signal; in this assay the cell line has been transformed with the luciferase gene. The GR RGA is described in detail in Willemsen et al. (2004). Briefly the glucocorticoid responsive TGRM-Luc cell line contains the MMTV-Luc luciferase reporter plasmid and the RS-hGR $\alpha$ expression vector which codes for the human GR. The luciferase acts as a signalling protein which is under the control of a highly regulated glucocorticoid inducible promoter resulting in transcriptional activation. Therefore the RGA is useful as a measurement of transcriptional activation due to the binding of a steroid hormone to its relevant receptor. 
The mixtures and individual POPs tested in this study did not exhibit an agonistic response in the TGRM-Luc cell line; the agonist activity for all compounds was below $0.13 \%$ (relative to a cortisol positive control). Results from the antagonistic test appeared to indicate adverse effects on the TGRMLuc nuclear receptor transcriptional activity for the two highest concentrations of PFC and PFC $+\mathrm{Br}$ mixtures ( $p \leq 0.001$; Figure $5 \mathrm{~A}$ and $\mathrm{B}$ ). However, it is reasonable to suggest that the reduction in the TGRM-Luc nuclear receptor transcriptional activity observed is solely as a result of the significant cytotoxic effects of both mixtures on this cell line (Figure 2B and E). The same explanation could be suggested for the antagonistic effects of PFOS (Figure 5C) observed at the two highest concentrations as they were also cytotoxic. However for the two lowest concentrations of PFOS (0.0147 and 0.0294 $\mathrm{mg} / \mathrm{ml} ; 500$ and 1000 times serum level), significant effects on the TGRM-Luc nuclear receptor transcriptional activity were found with no significant cytotoxicity. For these concentrations, transcriptional activity in the presence of cortisol increased to $114.4 \%$ and $120.7 \%$ ( $p \leq 0.05$ and $\leq$ 0.01 ) respectively. A similar effect was observed after incubation with the two highest concentrations of PFDA $(0.0025$ and $0.005 \mathrm{mg} / \mathrm{ml} ; 5000$ and 10000 times serum level), producing a response of $119.6 \%$ and $121.6 \%$ ( $p \leq 0.05$ both; Figure 5D) in comparison the positive control. In the PBDE group, BDE 47 at the highest concentration of $0.000086 \mathrm{mg} / \mathrm{ml}$ (10000 times serum level) also produced an increased response, 130.8\% ( $p \leq 0.05$; Figure 5E). Although not elucidated in this study upregulation of the GR expression by PFOS, PFDA and BDE-47 is a possibility for the observed result, where the increased levels of the receptor would provide cortisol with more of its relevant receptor target resulting in the increased response seen in the RGA. High PFOS levels have been associated with higher gene expression of the estrogen receptors $\alpha$ and $\beta(E R \alpha / \beta)$, the androgen receptor (AR) and the pregnane X receptor (PXR) (La Rocca et al. 2012).

The primary metabolite of dichlorodiphenyltrichloroethane (DDT), $p, p^{\prime}$-DDE exhibited an antagonistic effect on the TGRM-Luc nuclear receptor transcriptional activity (Figure 5F). When cells were exposed to the highest concentration of $p, p^{\prime}$-DDE $(0.005 \mathrm{mg} / \mathrm{ml})$, transcriptional activity was reduced to $72.5 \%$ compared to the positive control. This finding is supported by Zhao et al. (2004) who found that DDE significantly depressed GR-transactivation to $60 \%$ at a concentration of $0.0032 \mathrm{mg} / \mathrm{ml}$, which is similar to the concentration where significant GR antagonism was found in the present study $(0.005 \mathrm{mg} / \mathrm{ml})$. DDE is also known to be a potent AR antagonist (Kelce et al. 1995). In the present study, $p, p^{\prime}$-DDE led to significant antagonistic activity in the TGRM-Luc cell line however there was no evidence that any of the mixtures containing $p, p^{\prime}-\mathrm{DDE}$ (total, $\mathrm{Cl}, \mathrm{PFC}+\mathrm{Cl}$ or $\mathrm{Br}+\mathrm{Cl}$ ) caused $\mathrm{GR}$ translocation in the GR RA. This could suggest that $p, p^{\prime}$-DDE behaves differently in the presence of other compounds in mixtures. 
A

PFC Mix

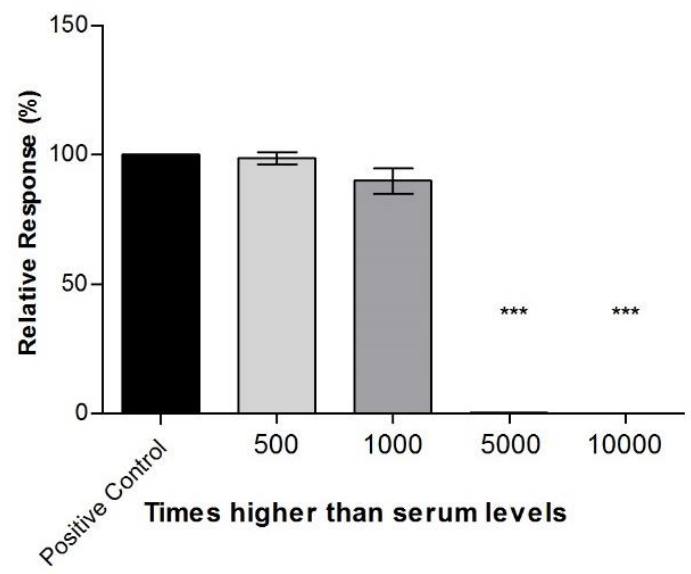

C

PFOS
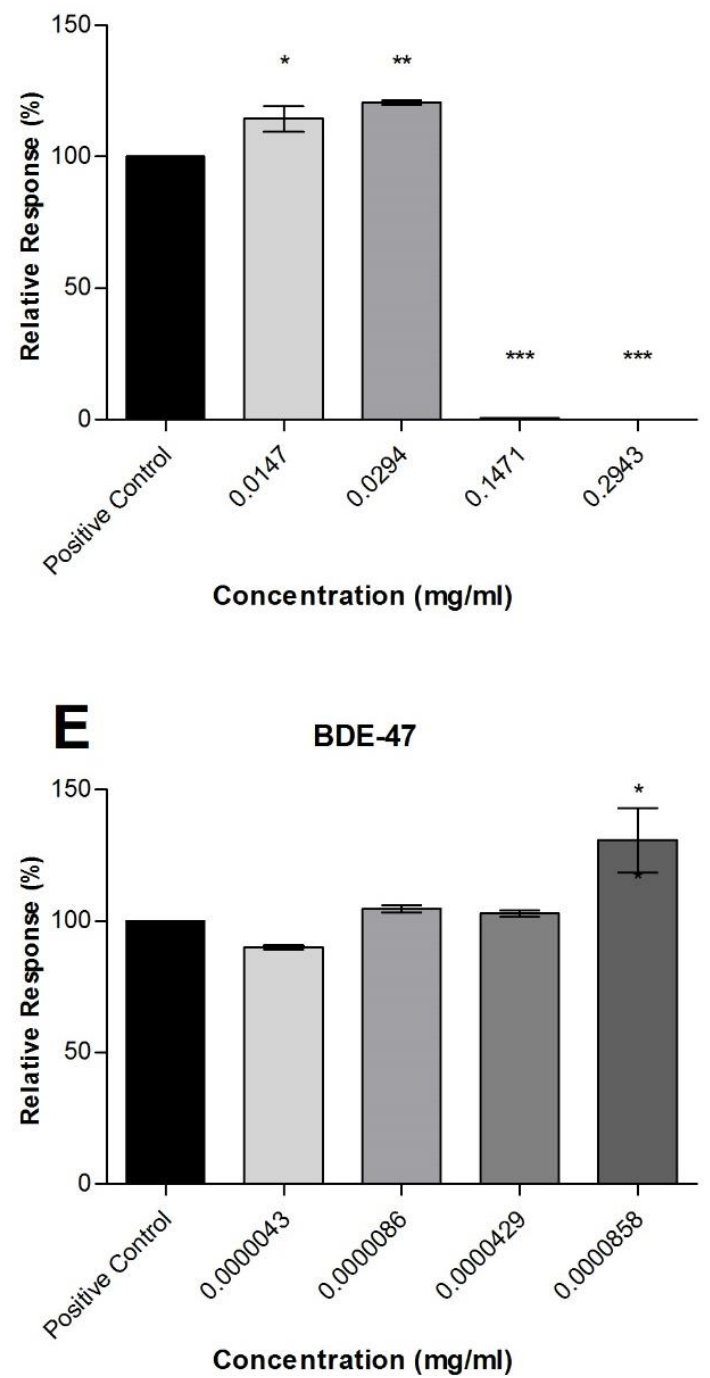
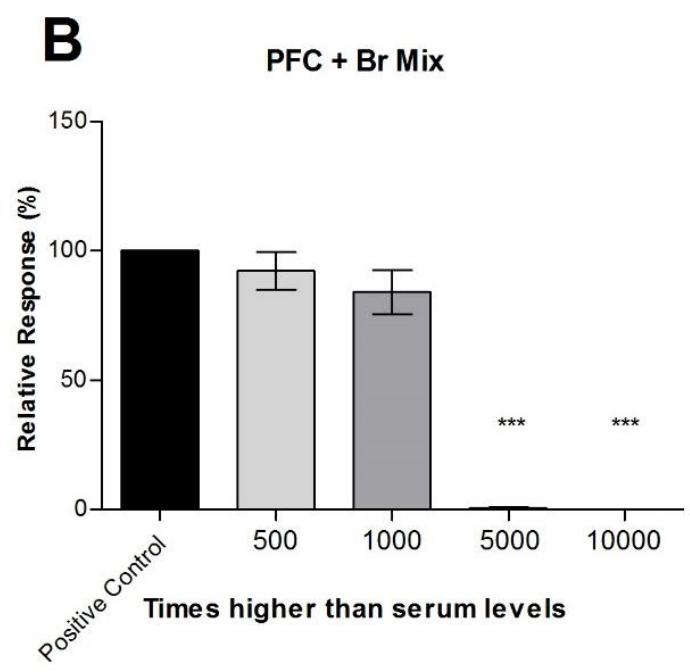

D

PFDA

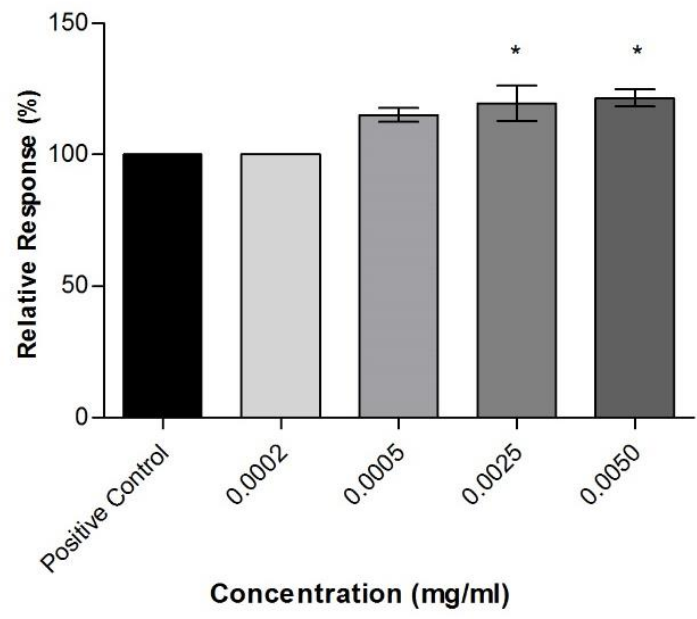

$\mathbf{F}$

$p, p^{\prime}-\mathrm{DDE}$

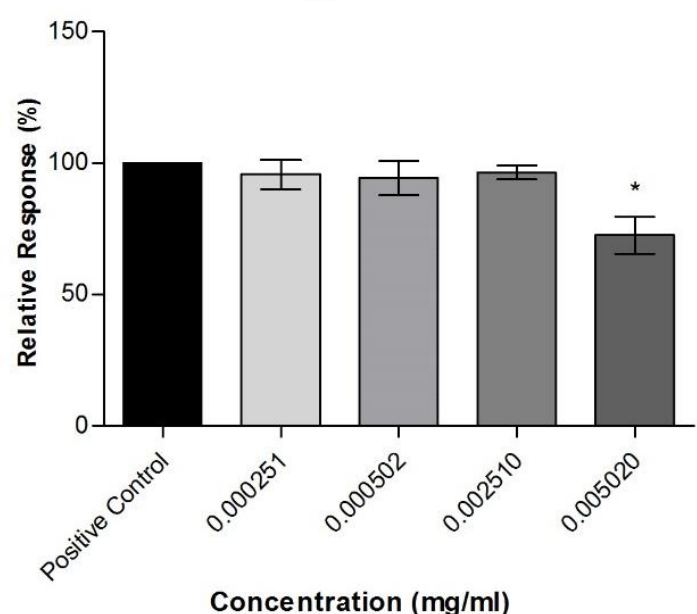

Figure 5: Antagonistic testing of mixtures and individual POPs using TGRM-Luc RGA. Positive control is

$441 \quad 90.6 \mathrm{ng} / \mathrm{ml}$ cortisol. Response is expressed as the percentage response \pm SEM for the two separate experiments $(\mathrm{n}=2) p \leq 0.05\left({ }^{*}\right), p \leq 0.01\left(^{* *}\right)$ and $p \leq 0.001\left(^{* * *}\right)$ represent significant antagonist effects. Only compounds which had significant results are shown. 
446 4. Conclusions

447 This study was designed to investigate mixtures and individual POPs for their potential to disrupt GR 448 transcriptional activity. POP mixtures did not induce GR translocation in the HCA GR RA or produce an 449 agonist response in the GR RGA. However, an individual POP, $p, p^{\prime}$-DDE $(0.005 \mathrm{mg} / \mathrm{ml})$, was found to 450 decrease the transcriptional activity of the glucocorticoid responsive TGRM-Luc cell line. Significant 451 increases in the TGRM-Luc nuclear receptor transcriptional activity, in the presence of cortisol, was 452 evident for the two lowest concentrations of PFOS $(0.0147$ and $0.0294 \mathrm{mg} / \mathrm{ml})$, the two highest 453 concentrations of PFDA $(0.0025$ and $0.005 \mathrm{mg} / \mathrm{ml})$ and the highest concentration of BDE-47 (0.000086 $454 \mathrm{mg} / \mathrm{ml}$ ). Upregulation of the GR expression by PFOS, PFDA and BDE-47 is a possibility for the observed 455 result, where the increased levels of the receptor would provide cortisol with more of its relevant 456 receptor target resulting in the increased response seen in the RGA however this is outside the scope 457 of this study. As the disruption of glucocorticoid synthesis and action is expected to contribute to 458 complex diseases (Odermatt and Gumy 2008) it is important to gain a better understanding of how 459 POPs may interact and affect this.

460

461 Acknowledgements:

462 This study was supported by PhD Studentship funding provided by the Department of Agriculture and 463 Rural Development (DARD) Northern Ireland and also by the Norwegian Research Council - Project: $46421307 / \mathrm{H} 10$. 
References: localization of the glucocorticoid receptor in mammalian cells and of glucocorticoid hormone-induced effects. Journal of Histochemistry and Cytochemistry; 42(5), 645-657.

Angelier, F., Clément-Chastel, C., Welcker, J., Gabrielsen, G.W., Chastel, O. (2009). How does corticosterone affect parental behaviour and reproductive success? A study of prolactin in black-legged kittiwakes. Functional Ecology; 23(4), 784-793.

Angelier, F., Wingfield, J.C., Weimerskirch, H., Chastel, O. (2010). Hormonal correlates of individual quality in a long-lived bird: a test of the 'corticosterone-fitness hypothesis'. Biology Letters; 6(6), 846-849.

Asp, V., Ullerås, E., Lindström, V., Bergström, U., Oskarsson, A., Brandt, I. (2010). Biphasic hormonal responses to the adrenocorticolytic DDT metabolite 3-methylsulfonyl-DDE in human cells. Toxicology and Applied Pharmacology; 242(3), 281-289.

Barrass, N., Steward, M., Warburton, S., Aitchison, J., Jackson, D., Wadsworth, P., Marsden, A., Orton, T. (1993) Cell proliferation in the liver and thyroid of C57B1/10J mice after dietary administration of chlordane. Environmental Health Perspectives; 101, 219-224.

Beesoon, S., Webster, G.M., Shoeib, M., Harner, T., Benskin, J.P., Martin, J.W. (2011). Isomer profiles of perfluorochemicals in matched maternal, cord, and house dust samples: manufacturing sources and transplacental transfer. Environmental Health Perspectives; 119, 1659-1664.

Berntsen, H.F., Berg, V., Thomsen, C., Lyche, J.L, Ropstad, E., Zimmer, K.E. (2015). The Synthesis of an Environmentally Relevant Mixture of Persistent Organic Pollutants for Use in In Vivo and In Vitro Studies. Manuscript in preparation.

Bi, X., Qu, W., Sheng, G., Zhang, W., Mai, B., Chen, D., Yu, L., Fu, J. (2006). Polybrominated diphenyl ethers in South China maternal and fetal blood and breast milk. Environmental Pollution; 144(3), 1024-1030.

Birnbaum, L.S., Staskal, D.F. (2004). Brominated flame retardants: cause for concern? Environmental Health Perspectives; 112, 9-17.

Boas, M., Feldt-Rasmussen, U., Skakkebaek, N.E., Main, K.M. (2006). Environmental chemicals and thyroid function. European Journal of Endocrinology; 154, 599-611.

Bókony, V., Lendvai, Á.Z., Liker, A., Angelier, F., Wingfield, J.C., Chastel, O. (2009). Stress response and the value of reproduction: are birds prudent parents? The American Naturalist; 173(5), 589-598.

Charmandari, E., Tsigos, C., Chrousos, G. (2005). Endocrinology of the stress response. Annual Review of Physiology; 67, 259-284.

Chuang, L.F., Liu, Y., Killam, K., Chuang, R.Y. (1992). Modulation by the insecticides heptachlor and chlordane of the cell-mediated immune proliferative responses of rhesus monkeys. In Vivo; 6, 29-32.

Cole, T.J., Blendy, J.A., Monaghan, A.P., Krieglstein, K., Schmid, W., Aguzzi, A., Fantuzzi, G., Hummler, E., Unsicker, K. Schütz, G. (1995). Targeted disruption of the glucocorticoid receptor gene blocks adrenergic chromaffin cell development and severely retards lung maturation. Genes and Development; 9, 1608-1621.

Darnerud, P.O. (2003) Toxic effects of brominated flame retardants in man and in wildlife. Environment International; 29, 841-853.

de Kloet E.R., Vreugdenhil E., Oitzl, M.S., Joels, M. (1998). Brain corticosteroid receptor balance in health and disease. Endocrine Reviews; 19(3), 269-301. 
de Wit, C., Fisk, A., Hobbs, K., Muir, D., Gabrielsen, G., Kallenborn, R., Krahn, M.M., Norstrom, R., Skaare, J. (2004). AMAP Assessment 2002: Persistent Organic Pollutants in the Arctic. Arctic Monitoring and Assessment Program, Oslo, Norway, xvi + 310pp.

EPA (2013). U.S. Environmental Protection Agency. Perfluorooctanoic Acid (PFOA) and Fluorinated Telomers. Available at: http://www.epa.gov/opptintr/pfoa/index.html. Accessed 20.06.15.

Florentin, A., Deblondea, T., Diguioa, N., Hautemanierea, A., Hartemanna, P. (2011). Impacts of two perfluorinated compounds (PFOS and PFOA) on human hepatoma cells: Cytotoxicity but no genotoxicity? International Journal of Hygiene and Environmental Health; 214, 493- 499.

Gendron, A.D., Bishop, C.A., Fortin, R., Hontela, A. (1997). In vivo testing of the functional integrity of the corticosterone-producing axis in mudpuppy (amphibia) exposed to chlorinated hydrocarbons in the wild. Environmental Toxicology and Chemistry; 16(8), 1694-1706.

Ghosh, S., De, S., Chen, Y., Sutton, D.C., Ayorinde, F.O., Dutta, S.K. (2010). Polychlorinated Biphenyls (PCB-153) and (PCB-77) absorption in human liver (HepG2) and kidney (HK2) cells in vitro: PCB levels and cell death. Environment International; 36(8), 893-900.

Goutte, A., Clément-Chastel, C., Moe, B., Bech, C., Gabrielsen, G.W., Chastel O. (2011). Experimentally reduced corticosterone release promotes early breeding in black-legged kittiwakes. Journal of Experimental Biology; 214(12), 2005-2013.

Haug, L.S., Thomsen, C., Brantsaeter, A.L., Kvalem, H.E., Haugen, M., Becher, G., Alexander, J., Meltzer, H.M., Knutsen, H.K. (2010). Diet and particularly seafood are major sources of perfluorinated compounds in humans. Environment International; 36, 772-778.

He, P., He, W, Wang, A., Xia, T., Xu, B., Zhang, M., Chen, X. (2008). PBDE-47-induced oxidative stress, DNA damage and apoptosis in primary cultured rat hippocampal neurons. Neurotoxicology; 29(1), 124-129.

He, W., He, P., Wang, A., Xia, T., Xu, B., Chen X. (2009). Effects of PBDE-47 on cytotoxicity and genotoxicity in human neuroblastoma cells in vitro. Mutation Research; 8; 649(1-2), 62-70.

Hirata-Koizumi, M., Fujii, S., Furukawa, M., Ono, A, Hirose, A. (2012). Repeated dose and reproductive/developmental toxicity of perfluorooctadecanoic acid in rats. Journal of Toxicological Sciences; 37 , 63-79.

Hu, X.Z., Xu, Y., Hu, D.C., Hui, Y., Yang, F.X. (2007). Apoptosis induction on human hepatoma cells HepG2 of decabrominated diphenyl ether (PBDE-209). Toxicology Letters; 15; 171(1-2), 19-28.

Inoue, K., Okada, F., Ito, R., Kato, S., Sasaki, S., Nakajima, S., Uno, A., Saijo, Y., Sata, F., Yoshimura, Y., Kishi, R., Nakazawa, H. (2004) Perfluorooctane Sulfonate (PFOS) and Related Perfluorinated Compounds in Human Maternal and Cord Blood Samples: Assessment of PFOS Exposure in a Susceptible Population during Pregnancy. Environmental Health Perspectives; 112, 1204-1207.

Johansson, M., Nilsson, S., Lund, B.O. (1998). Interactions between methylsulfonyl PCBs and the glucocorticoid receptor. Environmental Health Perspectives; 106(12), 769-774.

John, S., Sabo, P.J., Johnson, T.A., Sung, M.H., Biddie, S.C., Lightman, S.L., Voss, T.C., Davis, S.R., Meltzer, P.S., Stamatoyannopoulos, J.A., Hager, G.L. (2008). Interaction of the glucocorticoid receptor with the global chromatin landscape. Molecular Cell; 29, 611-624.

Jondal, M., Pazirandeh, A., Okret, S. (2004). Different roles for glucocorticoids in thymocyte homeostasis? Trends in Immunology; 25, 595-600.

Jönsson, C.J., Lund, B.O., Brandt, I. (1993). Adrenocorticolytic DDTmetabolites: studies in mink, Mustela vison and otter, Lutra lutra. Ecotoxicology; 2(1), 41-53. 
Joseph, S., D'Auvergne, O. (2012). Characterization of KISS-1 Expression and Cell Viability in MCF7 Breast Cancer Cells After Exposure to Gamma-Hexachlorocyclohexane. Journal of the Federation of American Societies for Experimental Biology; 26, Ib71.

Juruena, M.F., Cleare, A.J., Bauer, M.E., Pariante, C.M. (2003). Molecular mechanism of GR sensitivity and relevance for affective disorders for special issue Acta Neuropsychiatrica; 15(3), 354-367.

Kelce, W.R., Stone, C.R., Laws, S.C., Gray, L.E., Kemppainen, J.A., Wilson, E.M. (1995). Persistent DDT metabolite $p, p^{\prime}-D D E$ is a potent androgen receptor antagonist. Nature; $375,581-585$.

Keller-Wood M.E., Dallman M.F. (1984). Corticosteroid inhibition of ACTH secretion. Endocrine Reviews; 5(1), 124.

Knutsen, H.K., Kvalem, H. E., Thomsen, C., Froshaug, M., Haugen, M., Becher, G., Alexander, J., Meltzer, H. M. (2008). Dietary exposure to brominated flame retardants correlates with male blood levels in a selected group of Norwegians with a wide range of seafood consumption. Molecular Nutrition and Food Research; 52, 217-227.

Kraugerud, M., Zimmer, K.E., Ropstad, E., Verhaegen, S. (2011). Perfluorinated compounds differentially affect steroidogenesis and viability in the human adrenocortical carcinoma (H295R) in vitro cell assay. Toxicology Letters; 205(1), 62-68.

La Rocca, C., Alessi, E., Bergamasco, B., Caserta, D., Ciardo, F., Fanello, E., Focardi, S., Guerranti, C., Stecca, L., Moscarini, M., Perra, G., Tait, S., Zaghi, C., Mantovani, A. (2012). Exposure and effective dose biomarkers for perfluorooctane sulfonic acid (PFOS) and perfluorooctanoic acid (PFOA) in infertile subjects: preliminary results of the PREVIENI project. International Journal of Hygiene and Environmental Health; 215, 206-211.

Langlois, D., Li, J.Y., Saez, J.M. (2002). Development and function of the human fetal adrenal cortex. Journal of Pediatric Endocrinology and Metabolism; 15, 1311-1322.

Lanoix, D., Plusquellec, P. (2013). Adverse effects of pollution on mental health: the stress hypothesis. OA Evidence-Based Medicine; 1(1), 6.

Li, L.A., Wang, P.W. (2005). PCB126 induces differential changes in androgen, cortisol, and aldosterone biosynthesis in human adrenocortical H295R cells. Toxicological Sciences; 85(1), 530-540.

Lu, Z., Tharappel, J.C., Lee, E.Y., Robertson, L.W., Spear, B.T. and Glauert, H.P. (2003). Effect of a single dose of polychlorinated biphenyls on hepatic cell proliferation and the DNA binding activity of NF-KB and AP-1 in rats. Molecular Carcinogenesis; 37, 171-180.

Madia, F., Giordano, G., Fattori, V., Vitalone, A., Branchi, I., Capone, F., Costa, L.G. (2004). Differential in vitro neurotoxicity of the flame retardant PBDE-99 and of the PCB Aroclor 1254 in human astrocytoma cells. Toxicology Letters; 154(1-2), 11-21.

Maras, M., Vanparys, C., Muylle, F., Robbens, J., Berger, U., Barber, J.L., Blust, R., De Coen, W. (2006). Estrogenlike properties of fluorotelomer alcohols as revealed by MCF-7 breast cancer cell proliferation. Environmental Health Perspectives; 114, 100-105.

Martinez-Aguayo, A., Aglony, M., Bancalari, R., Avalos, C., Bolte, L., Garcia, H., Loureiro, C., Carvajal, C., Campino, C., Inostroza, A., Fardella, C. (2011). Birth weight is inversely associated with blood pressure and serum aldosterone and cortisol levels in children. Clinical Endocrinology; 76, 713-718.

Mayne, G.J., Martin, P.A., Bishop, C.A., Boermans, H.J. (2004). Stress and immune responses of nestling tree swallows (Tachycineta bicolor) and eastern bluebirds (Sialia sialis) exposed to nonpersistent pesticides and $p, p$, , dichlorodiphenyldichloroethylene in apple orchards of southern Ontario, Canada. Environmental Toxicology and Chemistry; 23(12), 2930-2940. 

toxicity. Journal of Biological Chemistry; 274 (15), 10349-10355.

Ode, A., Rylander, L., Lindh, C.H., Källén, K., Jönsson, B.A., Gustafsson, P., Olofsson, P., Ivarsson, S.A., RignellHydbom, A. (2013). Determinants of maternal and fetal exposure and temporal trends of perfluorinated compounds. Environmental Science and Pollution Research; 20, 7970-7978.

Odermatt, A., Gumy, C. (2008). Glucocorticoid and mineralocorticoid action: why should we consider influences by environmental chemicals? Biochemical Pharmacology; 76(10), 1184-1193.

Odermatt, A., Gumy, C., Atanasov, A.G., Dzyakanchuk, A.A. (2006). Disruption of glucocorticoid action by environmental chemicals: potential mechanisms and relevance. Journal of Steroid Biochemistry and Molecular Biology; 102, 222-231.

Oskarsson, A., Ullerås, E., Plant, K.E., Hinson, J.P., Goldfarb, P.S. (2006). Steroidogenic gene expression in H295R cells and the human adrenal gland: adrenotoxic effects of lindane in vitro. Journal of Applied Toxicology; 26(6), 484-492.

Pereg, D., Ryan, J.J., Ayotte, P., Muckle, G., Patry, B., Dewailly, E. (2003). Temporal and spatial changes of brominated diphenyl ethers (BDEs) and other POPs in human milk from Nunavik (Arctic) and southern Quebec. Organohalogen Compounds; $61,127-130$.

Pimenta, E., Wolley, M., Stowasser, M. (2012). Adverse cardiovascular outcomes of corticosteroid excess. Endocrinology; 153, 5137-5142.

Polder, A., Skaare, J.U., Skjerve, E., Loken, K.B., Eggesbo, M. (2009). Levels of chlorinated pesticides and polychlorinated biphenyls in Norwegian breast milk (2002-2006), and factors that may predict the level of contamination. Science of the Total Environment; 407, 4584-4590.

Polder, A., Thomsen, C., Lindstrom, G., Loken, K.B., Skaare, J.U. (2008). Levels and temporal trends of chlorinated pesticides, polychlorinated biphenyls and brominated flame retardants in individual human breast milk samples from Northern and Southern Norway. Chemosphere; 73, 14-23.

Pratt, W.B., Toft, D.O. (1997). Steroid receptor interactions with heat shock protein and immunophilin chaperones. Endocrine Reviews; 18, 306-360.

Reistad, T., Fonnum, F., Mariussen, E. (2006). Neurotoxicity of the pentabrominated diphenyl ether mixture, DE71 , and hexabromocyclododecane (HBCD) in rat cerebellar granule cells in vitro. Archives of Toxicology; 80(11), 785-796.

Ricklefs, R.E., Wikelski, M. (2002). The physiology/life-history nexus. Trends in Ecology and Evolution; 17(10), 462-468.

Rosenfeld M.G. and Glass C.K. (2001). Coregulator codes of transcriptional regulation by nuclear receptors. Journal of Biological Chemistry; 276, 36865-36868.

Ruiz, M.J., Festila, L.E., Fernández, M. (2006). Comparison of basal cytotoxicity of seven carbamates in CHO-K1 cells. Toxicological and Environmental Chemistry; 88(2), 345-354.

Sapolsky, R.M., Romero, L.M., Munck, A.U. (2000). How do glucocorticoids influence stress responses? Integrating permissive, suppressive, stimulatory, and preparative actions. Endocrine Reviews; 21, 55-89.

Sargis, R.M., Johnson, D.N., Choudhury, R.A., Brady, M.J. (2009). Environmental Endocrine Disruptors Promote Adipogenesis in the 3T3-L1 Cell Line through Glucocorticoid Receptor Activation. Obesity (Silver Spring); 18 (7), $1283-1288$. 
Schantz, S.L., Widholm, J.J. (2001). Cognitive effects of endocrine-disrupting chemicals in animals. Environmental Health Perspectives; 109, 1197-1206.

Schreiber, T., Gassmann, K., Götz, C., Götz, C., Hübenthal, U., Moors, M., Krause, G., Merk, H.F., Nguyen, N., Scanlan, T.S., Abel, J., Rose, C.R., Fritsche, E. (2010). Polybrominated Diphenyl Ethers Induce Developmental Neurotoxicity in a Human in Vitro Model: Evidence for Endocrine Disruption. Environmental Health Perspectives; 118(4), 572-578.

Shabalina, I.G., Panaretakis, T., Bergstrand, A., DePierre, J.W. (1999). Effects of the rodent peroxisome proliferator and hepatocarcinogen, Perfluorooctanoic acid, on apoptosis in human hepatoma HepG2 cells. Carcinogenesis; 20, 2237-2246.

Shao, J., White, C.C., Dabrowski, M.J., Kavanagh, T.J., Eckert, M.L., Gallagher, E.P. (2008). The role of mitochondrial and oxidative injury in BDE 47 toxicity to human fetal liver hematopoietic stem cells. Toxicological Sciences; 101(1), 81-90.

Sjödin, A., Hagmar, L., Klasson-Wehler, E., Kronholm-Diab, K., Jakobsson, E., Bergman, A. (1999). Flame retardant exposure: polybrominated diphenyl ethers in blood from Swedish workers. Environmental Health Perspectives; 107(8), 643-648.

Sjödin, A., Wong, L.Y., Jones, R.S., Park, A., Zhang, Y., Hodge, C., Dipietro, E., McClure, C., Turner, W., Needham, L.L., Patterson, D.G. Jr. (2008). Serum concentrations of polybrominated diphenyl ethers (PBDEs) and polybrominated biphenyl (PBB) in the United States population: 2003-2004. Environmental Science and Technology; 15, 42(4), 1377-1384.

Slater, T.F., Sawyer, B., Strauli, U.D. (1963). Studies on succinate-tetrazolium reductase systems. III. Points of coupling of four different tetrazolium salts. Biochimica et Biophysica Acta; 77, 383-393.

Song, R.F., He, Y.H., Murphy, M.B., Yeung, L.W.Y., Yu, R.M.K., Lam, M.H.W., Lam, P.K.S., Hecker, M., Giesy, J.P., Wu, R.S.S., Zhang, W.B., Sheng, G.Y., Fu, J.M. (2008). Effects of fifteen PBDE metabolites, DE71, DE79 and TBBPA on steroidogenesis in the H295R cell line. Chemosphere; 71(10), 1888-1894.

Tsigos, C., Chrousos, G.P. (2002). Hypothalamic-pituitary-adrenal axis, neuroendocrine factors and stress. Journal of Psychosomatic Research; 53(4), 865-871.

Ullerås, E., Ohlsson, A., Oskarsson, A. (2008). Secretion of cortisol and aldosterone as a vulnerable target for adrenal endocrine disruption - screening of 30 selected chemicals in the human H295R cell model. Journal of Applied Toxicology; 28(8), 1045-1053.

United Nations Environment Program (UNEP), Final Act of the Conference of Plenipotentiaries on The Stockholm Convention on Persistent Organic Pollutants, Stockholm, Sweden, 22 to 23 May 2001 (UNEP, Geneva, Switzerland, 2001).

Van Oostdam, J.C., Dewailly, E., Gilman, A., Hansen, J.C., Odland, J.O., Chashchin, V., Bernenr, J., Butler-Walker, J., Lagerkvist, B. J., Olafsdottir, K., Soininen, L., Bjerregard, P., Klopov, V., Weber, J.P. (2004). Circumpolar maternal blood contaminant survey, 1994-1997 organochlorine compounds. Science of the Total Environment; 330, 55-70.

Verboven, N., Verreault, J., Letcher, R.J., Gabrielsen, G.W., Evans, N.P. (2010). Adrenocortical function of Arcticbreeding glaucous gulls in relation to persistent organic pollutants. General and Comparative Endocrinology; 166(1), 25-32.

Wan Ibrahim W.N., Tofighi R., Onishchenko, N., Rebellato, P., Bose, R., Uhlen, P., Ceccatelli, S. (2013). Perfluorooctane sulfonate induces neuronal and oligodendrocytic differentiation in neural stem cells and alters the expression of PPARgamma in vitro and in vivo. Toxicology and Applied Pharmacology; 269, 51-60. 
Whysner, J., Wang, C.X. (2001). Hepatocellular iron accumulation and increased cell proliferation in polychlorinated biphenyl-exposed sprague-dawley rats and the development of hepatocarcinogenesis. Toxicological Sciences; 62, 36-45.

Willemsen, P., Scippo, M., Kausel, G., Figueroa, J., Maghuin-Rogister, G., Martial, J. (2004). Use of reporter cell lines for detection of endocrine-disrupter activity. Analytical and Bioanalytical Chemistry; 378 (3), 655-663.

Wingfield, J.C., Sapolsky, R.M. (2003). Reproduction and resistance to stress: when and how. Journal of Neuroendocrinology; 15(8), 711-724. cells. Chemosphere; 63(5), 772-784.

Zhang, J., Liang, J., Zhu, H., Li C., Wu, Q. (2013). PFOS and PCB 153 Have Direct Adverse Effects on Neonatal Testis Modeled Using a Coculture of Primary Gonocyte and Sertoli Cells. Environmental Toxicology; 28(6), 322-331.

Zhang N., Wang W.S., Li W.J., Liu C., Wang Y., Sun K. (2015). Reduction of progesterone, estradiol and hCG secretion by perfluorooctane sulfonate via induction of apoptosis in human placental syncytiotrophoblasts. Placenta; 36(5), 575-580.

Zhao, J., Bauman, W.A., Huang, R., Caplan, A.J., Cardozo, C. (2004). Oxandrolone blocks glucocorticoid signaling in an androgen receptor-dependent manner. Steroids; 69 (5), 357-366.

Zoeller, R.T. (2005). Environmental chemicals as thyroid hormone analogues: new studies indicate that thyroid hormone receptors are targets of industrial chemical? Molecular and Cellular Endocrinology; 242 (1-2), 10-15. 